\title{
Identification of a WSSV neutralizing ScFv antibody by phage display technology and in vitro screening
}

\author{
Li Yuan ${ }^{1,2}$, Xiaohua Zhang ${ }^{1}$, Nan Xiao ${ }^{1,2}$, Lingfen Dai ${ }^{1}$, Weizhou Chen ${ }^{3}$, \\ Chensong Jia ${ }^{1}$, Ruohong Zhao ${ }^{4}$, Sean M. Hemmingsen ${ }^{4}$, Heping Dai ${ }^{1, *}$ \\ ${ }^{1}$ Institute of Hydrobiology, Chinese Academy of Sciences, 7 East Lake Southern Road, Wuhan 430072, PR China \\ ${ }^{2}$ Graduate School of the Chinese Academy of Sciences, Beijing 100039, PR China \\ ${ }^{3}$ Marine Biology Laboratory Nanao Station, Key Laboratory of Marine Biology of Guangdong Province, Shantou University, \\ Shantou 515900, PR China \\ ${ }^{4}$ Plant Biotechnology Institute, National Research Council of Canada, 110 Gymnasium Place, Saskatoon S7N 0W9, Canada
}

\begin{abstract}
White spot syndrome virus (WSSV) is one of the most significant viral pathogens causing high mortality and economic damage in shrimp aquaculture. Although intensive efforts were undertaken to detect and characterize WSSV infection in shrimp during the last decade, we still lack methods either to prevent or cure white spot disease. Most of the studies on neutralizing antibodies from sera have been performed using in vivo assays. For the first time, we report use of an in vitro screening method to obtain a neutralizing scFv antibody against WSSV from a previously constructed anti-WSSV single chain fragment variable region (scFv) antibody phage display library. From clones that were positive for WSSV by ELISA, 1 neutralizing $\mathrm{scFv}$ antibody was identified using an in vitro screening method based on shrimp primary lymphoid cell cultures. The availability of a neutralizing antibody against the virus should accelerate identification of infection-related genes and the host cell receptor, and may also enable new approaches to the prevention and cure of white spot disease.
\end{abstract}

KEY WORDS: White spot syndrome virus $(\mathrm{WSSV}) \cdot$ Phage display $\cdot$ Neutralizing antibody $\cdot$ Single chain fragment variable regions ( $\mathrm{scFv}$ ) antibody

Resale or republication not permitted without written consent of the publisher

\section{INTRODUCTION}

An outbreak of white spot syndrome virus (WSSV) was first reported in 1992 in northern Taiwan (Chou et al. 1995) and the disease is now globally disseminated (Takahashi et al. 1994, Huang et al. 1995, Wang et al. 1995, Wongteerasupaya et al. 1995). The virus not only exists in shrimp but also occurs in other freshwater and marine crustaceans, including crabs and crayfish (Lo et al. 1996, Wang et al. 1998). WSSV infection can cause cumulative mortality of up to $100 \%$ within 3 to $10 \mathrm{~d}$ (Lightner 1996). As such, WSSV has become an epizootic disease and is not only a major threat to shrimp culture but also to marine ecology (Flegel 1997).

Electron microscopy studies show that the WSSV virion is an ellipsoid to bacilliform, enveloped particle with a tail-like appendage at one end. The virion con- tains a rod-shaped nucleocapsid, typically measuring $275 \mathrm{~nm}$ in length and $120 \mathrm{~nm}$ in width (Wongteerasupaya et al. 1995). It has a large circular doublestranded DNA of about 290 to $305 \mathrm{~kb}$ (van Hulten et al. 2001a, Yang et al. 2001). The International Committee on Taxonomy of Viruses approved a proposal to erect WSSV as the type species of the genus Whispovirus, family Nimaviridae (Mayo 2002).

Since the WSSV total genome sequence was reported in 2001 (van Hulten et al. 2001a, Yang et al. 2001), studies have identified 39 potential structural proteins, including VP28, VP26, VP24, VP19 and VP15 etc., which were identified by polyacrylamide gel electrophoresis (Tsai et al. 2004) or characterized after cloning and expression of the coding sequences in Escherichia coli. Nevertheless, genes that are required for infection remain to be identified, and study of the 
interaction between virus proteins and host cell receptors is required. Although WSSV has double-stranded DNA and an enveloped virion that resembles baculoviruses in shape, WSSV proteins have no homology either to known baculovirus proteins or to other viral proteins in databases (van Hulten et al. 2000a,b, 2001a, van Hulten \& Vlak 2001) Therefore, it is difficult to infer molecular mechanisms of infection from comparisons with known viruses. Only limited studies of WSSV infection in shrimp cells cultured in vitro have been conducted, and a shrimp continuous cell line has not yet been established.

Neutralizing antibodies are well recognized as effective tools for prevention and cure of viral diseases and for studies of the molecular mechanisms of viral infection. Monoclonal antibodies against WSSV (Poulos et al. 2001, Anil et al. 2002, Liu et al. 2002) are not widely available, and a neutralizing monoclonal antibody against WSSV has not been reported. Most of the studies on neutralizing antibodies have been performed using in vivo assays (van Hulten et al. 2001b, Huang et al. 2005, Li et al. 2005, Wu et al. 2005) and some have used primary shrimp cell cultures (Yi et al. 2004). To obtain a neutralizing monoclonal antibody against WSSV, we constructed an anti-WSSV phage display scFv library and, through 4 rounds of selection, identified $\mathrm{scFv}$ antibodies that bind WSSV specifically. As we lacked a shrimp continuous cell line, we established an in vitro screening method for neutralizing antibodies that was based on shrimp primary cell cultures. The first step for virus infection is attachment to a host cell. We therefore assayed the inhibition of viral attachment to host cells to identify potentially neutralizing antibodies.

Several investigators have reported that WSSV infects primary cell cultures from lymphoid organs of Penaeus monodon (Kasornchandra et al. 1999, Wang et al. 2000), Litopenaeus stylirostris (also named Penaeus stylirostris or blue shrimp) (Tapay et al. 1997) and Marsupenaeus japonicus (also named Penaeus japonicus or kuruma shrimp) (Itami et al. 1999). These results showed that shrimp primary lymphoid cell culture can be used for a WSSV attachment test.

\section{MATERIALS AND METHODS}

Isolation and purification of WSSV. Viruses used in the construction of the phage display antibody library, panning and ELISA were isolated from infected Penaeus monodon shrimp either from Hainan Island or from Nan-ao Island in southern China. Haemolymph samples from infected shrimp were pooled and laid onto the top of a discontinuous sucrose gradient of 35 , 50 and $60 \%(\mathrm{w} / \mathrm{v})$, ultracentrifuged at $125000 \times g$ for
90 min at $4{ }^{\circ} \mathrm{C}$. The band containing the virus, located between the 50 and $60 \%$ sucrose zones, was collected using a syringe and dialyzed overnight against phosphate buffered saline (PBS) at $4^{\circ} \mathrm{C}$. Viruses used for in vitro screening for neutralizing antibodies were isolated from infected crayfish Cambarus clarkii, a practical source of WSSV (Maeda et al. 2000, Huang et al. 2001). The crayfish were bought from a market and were then infected by WSSV injection. Abundant viral particles could be obtained with only a few steps of conventional differential centrifugation, and no density gradient ultracentrifugation was involved (Xie et al. 2005). The tissues of 5 to 7 infected crayfish (excluding the hepatopancreas) were collected in an icebathed beaker. The infected tissues were homogenized in $500 \mathrm{ml}$ TNE buffer ( $50 \mathrm{mM}$ Tris- $\mathrm{HCl}, 400 \mathrm{mM}$ $\mathrm{NaCl}, 5$ mM EDTA, pH 8.5) containing a combination of protease inhibitors (1 mM phenylmethylsulfonyl fluoride [PMSF], $1 \mathrm{mM}$ benzamidine, and $1 \mathrm{mM}$ $\mathrm{Na}_{2} \mathrm{~S}_{2} \mathrm{O}_{5}$ ), and then centrifuged at $3500 \times g$ for 5 min at $4^{\circ} \mathrm{C}$. The supernatant was centrifuged at $26000 \times g$ for $30 \mathrm{~min}$ at $4^{\circ} \mathrm{C}$. Next, the upper loose pink pellet was rinsed out carefully, and the lower white pellet suspended in $10 \mathrm{ml}$ TM buffer $(50 \mathrm{mM}$ Tris- $\mathrm{HCl}, 10 \mathrm{mM}$ $\mathrm{MgCl}_{2}, \mathrm{pH}$ 7.5). After centrifugation at $3500 \times g$ for $5 \mathrm{~min}$, the virus particles were precipitated by centrifugation at $20000 \times g$ for $20 \mathrm{~min}$ at $4^{\circ} \mathrm{C}$, and were then resuspended and kept in $1 \mathrm{ml}$ TM buffer. In this experiment, tissues of uninfected crayfish were used as the control, but no white pellet could be obtained. The concentration of viral protein was measured by absorbance at $280 \mathrm{~nm}$ or tested by Bradford reagent.

Construction of phage display $\mathrm{scFv}$ antibody library. The library was constructed as described in previous work (Dai et al. 2003). Spleenic mRNA from a mouse immunized with WSSV was reverse-transcribed to produce a cDNA template for PCR amplification of antibody VL and $\mathrm{VH}$ regions. The phagemid vector used for construction of the library was pCANTAB 5E (Pharmacia). The ligated phagemid was electroporated into E. coli NM522 cells.

Phage rescue and bio-panning. The procedure for phage rescue and bio-panning was performed as described by Dai et al. (2003). The helper phage M13K07 was used to infect transformed E. coli NM522 cells for phage rescue. Titer of phage recovered from bio-panning rounds was determined with E. coli TG1 cells. Production of periplasmic extracts of soluble $\mathrm{ScFV}$ antibodies was conducted using the Pharmacia Expression Module according to manufacturer's instructions. After 4 rounds of selection, the positive clones were evaluated by ELISA. DNA sequencing of the clones encoding $\mathrm{ScFv}$ antibodies with binding activity to WSSV was carried out by Shanghai Bioasia Biological Engineering and Technology. 
ELISA. The E-tagged A1 antibody is the basis for the detection of WSSV by ELISA. ELISA plates (96well) were coated with the indicated concentration of WSSV at $4^{\circ} \mathrm{C}$ overnight, followed by blocking with $4 \%$ skim milk in PBS at room temperature for $1 \mathrm{~h}$. Soluble scFv antibodies, produced as previously described (Dai et al. 2003), were incubated with the coated WSSV at room temperature for $1 \mathrm{~h}$. After washing 3 times with PBST (PBS containing $0.1 \%$ Tween 20) and 3 times with PBS, bound ScFv antibodies were detected with the mouse monoclonal antibody HRP/Anti-E Tag conjugate (Pharmacia). TMB (3, 3', 5, 5' -tetramethylbenzidine) (Serva) was used for the color reaction with peroxidase, and absorbance was determined at $450 \mathrm{~nm}$.

Preparation of porcine polyclonal antibody against WSSV. A 70 d-old male pig was immunized with WSSV particles in Freund's Complete Adjuvant (100 $\mu \mathrm{g}$ WSSV protein per injection), followed by 3 booster injections of WSSV in Freund's incomplete adjuvant given at $2 \mathrm{wk}$ intervals. ELISA and dot-blot analysis were performed with sera from test bleeds. Seven days after the last injection, the pig was exsanguinated to collect the antiserum. The titer of the antiserum was assayed by ELISA. The porcine antiserum was partially purified by $50 \%$ saturation $\left(\mathrm{NH}_{4}\right)_{2} \mathrm{SO}_{4}$ precipitation.

Primary shrimp cell culture. Live Litopenaeus vannamei (also named Penaeus vannamei) shrimp used in this study were purchased from the market. The lymphoid organs were removed and rinsed 3 times with L15-PS culture medium (L-15 medium containing $100 \mathrm{IU} \mathrm{ml} \mathrm{m}^{-1}$ penicillin and $100 \mu \mathrm{g} \mathrm{ml} \mathrm{m}^{-1}$ streptomycin). The lymphoid organs were then transferred into $1.5 \mathrm{ml}$ of L15-PS culture medium, cut into small pieces and filtered through a single cell gauze filter. Single lymphoid cells were placed into 96-well cell culture plates with $40 \mu \mathrm{l}$ medium per well. After $2 \mathrm{~h}$, the L15-PS culture medium with or without $20 \%$ fetal bovine serum (FBS) was supplemented at $200 \mu \mathrm{l}$ per well. The cells were incubated at $27^{\circ} \mathrm{C}$ overnight to form a monolayer of cells attached to the bottom of the well.

Neutralizing antibody screen. Primary cultures of shrimp lymphoid cells were prepared and adsorbed on the 96-well plate. After a monolayer of cells had formed, the medium was removed. The wells were washed once with PBS to remove unattached cells. The plate was blocked with $3 \%$ BSA in L15-PS culture medium at $27^{\circ} \mathrm{C}$ for $1 \mathrm{~h}$. Meanwhile, quantities of experimental antibodies (as judged by ELISA signal upon binding to WSSV) or quantities of control antibodies or proteins (as judged by absorbance at $280 \mathrm{~nm}$ ) were pre-incubated with the indicated concentration of WSSV at $27^{\circ} \mathrm{C}$. After $1 \mathrm{~h}$, the pre-incubation mix- tures were added to the blocked primary cell culture wells and incubated at $27^{\circ} \mathrm{C}$ for $30 \mathrm{~min}$. The cell culture plate was washed gently 2 times with PBST and 2 times with PBS to remove unbound viruses. After immediate fixation of the cells with $4 \%$ paraformaldehyde for $10 \mathrm{~min}$ at $4^{\circ} \mathrm{C}$, the bound viruses were detected by ELISA.

\section{RESULTS}

\section{Production and purification of WSSV}

Since only intact, enveloped WSSV virions are infectious (Liang et al. 2002), 2 methods of purification of WSSV were investigated. Electron microscopy showed that the method with only a few steps of conventional differential centrifugations (Xie et al. 2005) produced a higher yield of intact, enveloped virions than the traditional method, which required sucrose density gradient ultracentrifugation (Fig. 1).

\section{Isolation of ScFv antibodies specific for WSSV}

A phage display library of $2.1 \times 10^{7}$ independent clones developed from mice immunized with WSSV was described previously by Dai et al. (2003). The selection and characterization from this library of the scFv antibody clone designated A1 has been reported (Dai et al. 2003, Zhang et al. 2006). A second anti-
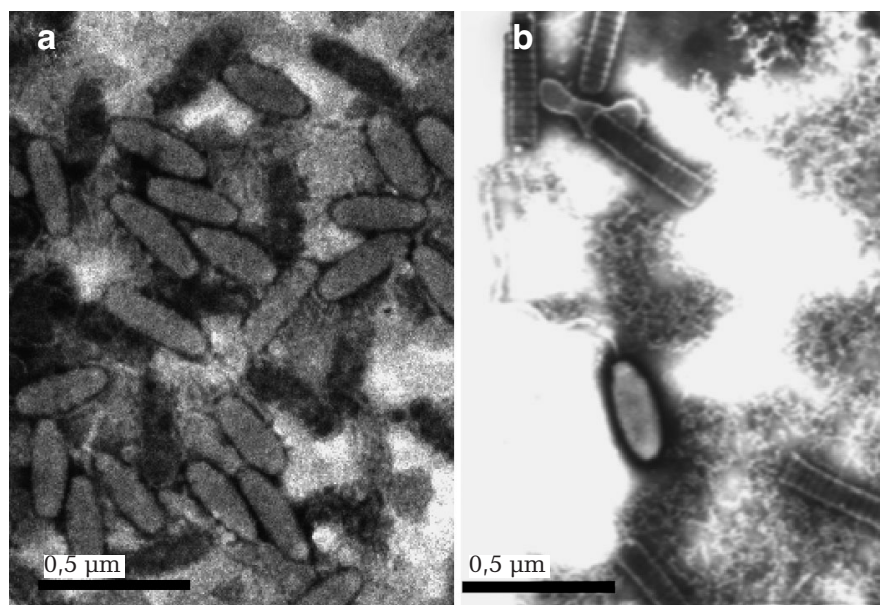

Fig. 1. Electron micrograph of negatively stained, intact WSSV virions purified by 2 different methods. (a) Virions isolated from tissues of infected crayfish Cambarus clarkii and purified with a few steps of conventional differential centrifugation. (b) Virions isolated from the haemolymph of infected Penaeus monodon shrimp and purified by sucrose density gradient centrifugation 


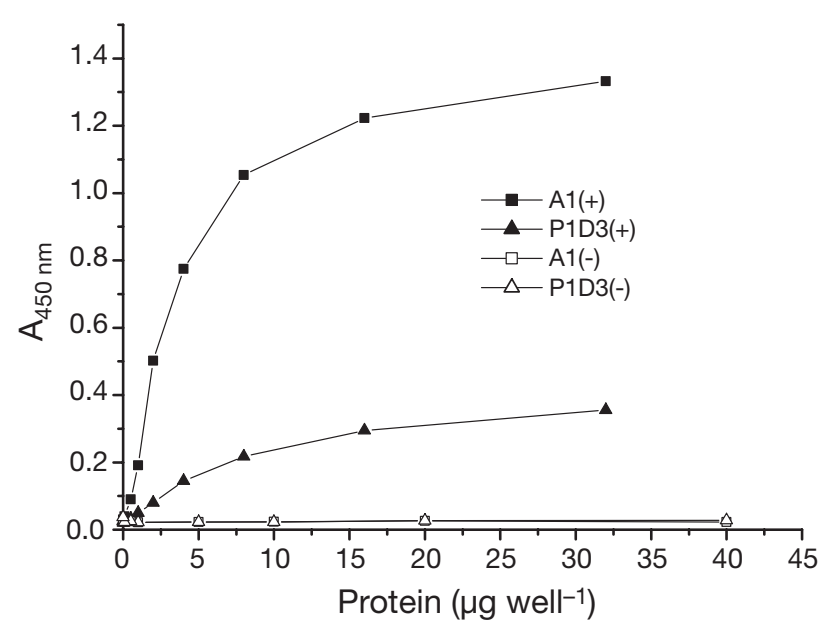

Fig. 2. ELISA assay for specificity of soluble scFv antibodies binding to WSSV. Microplates were coated with WSSV (+) $\left(0-32 \mu \mathrm{g}\right.$ viral protein well $\left.{ }^{-1}\right)$ or shrimp haemolymph protein $(-)$ as a negative control $(0-40 \mu \mathrm{g}$ shrimp haemolymph protein well ${ }^{-1}$ ). A1 or P1D3 scFv antibodies from periplasmic extracts were diluted 40 -fold

body recovered from this library was designated as P1D3.

The binding specificity of the A1 and P1D3 scFV antibodies was determined by ELISA. Both antibodies showed specific binding activity to WSSV (Fig. 2). Amino acid sequences of the $2 \mathrm{scFv}$ antibodies were deduced from their nucleic acid sequences (Fig. 3). The DNA sequences encoding ScFv antibodies A1 and P1D3 were submitted to GenBank (accession numbers DQ022661 and DQ022660, respectively). The heavychain regions of the $\mathrm{ScFV}$ antibodies showed more diversity than the light-chain regions. Overall, the 2 primary structures are very similar. However, as described below, the antibodies had different characteristics.

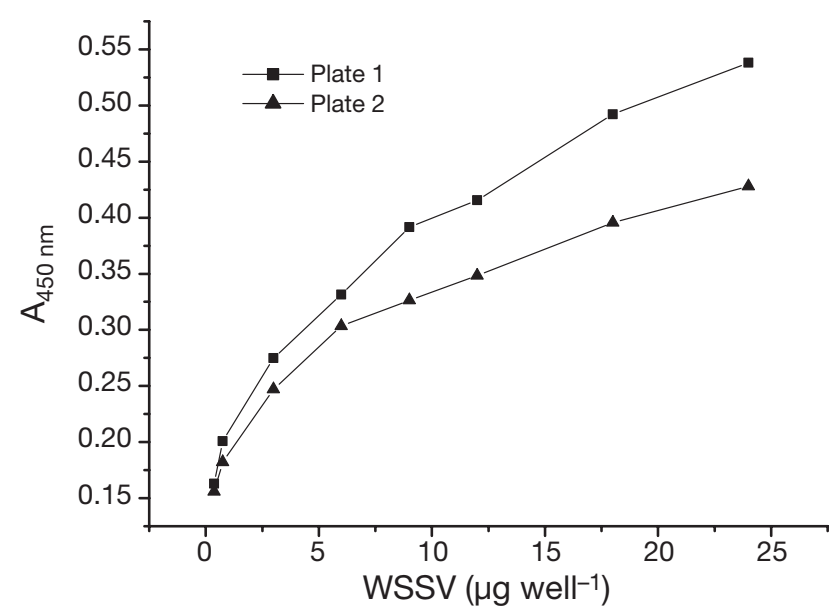

Fig. 4. WSSV binding activity to shrimp lymphoid cells in primary culture. Shrimp lymphoid cells cultured in L15-PS supplemented with $20 \%$ FBS (Plate 2) or in L15-PS without serum addition (Plate 1)

\section{Establishing the screening method}

The screening assay was based on the binding activity of viruses to host cells. To test WSSV binding activity to shrimp lymphoid cells in primary cultures, 2 kinds of cell culture media (with or without FBS in L15PS) were used. Microscopy revealed that, when cultured in L15-PS supplemented with $20 \%$ FBS, the lymphoid organ cells grew in a spindle shape and then formed net-like arrays. Without FBS, the cells always grew in a rounded shape. Both of these cell cultures could be maintained for at least $24 \mathrm{~h}$. The binding activities of WSSV to lymphoid cells of both shapes were compared. Fig. 4 shows that WSSV had higher binding activity to rounded cells cultured in L15-PS without serum addition.

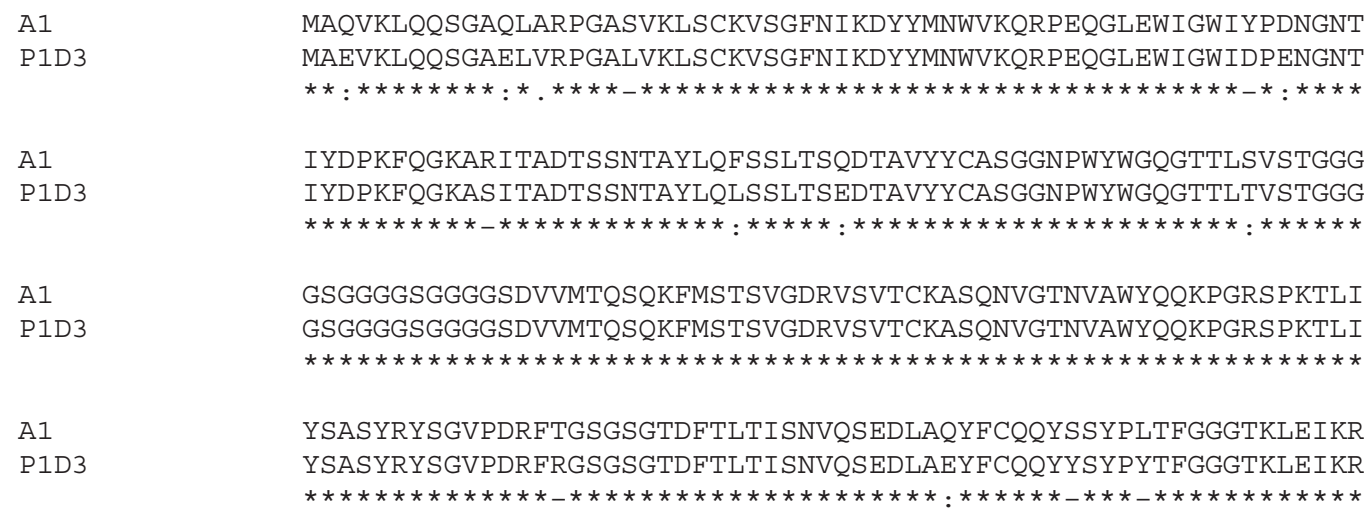

Fig. 3. Deduced amino acid sequences of scFv antibodies; the heavy-chain variable fragment (front) and light-chain variable fragment (back) were connected by a glycine rich linker (GGGGSGGGGSGGGGS). Alignment and comparison using ClustalX. (*) Fully conserved residue; (:) strong functional group conserved; (.) weak functional group conserved; (-) no conserved functionality 


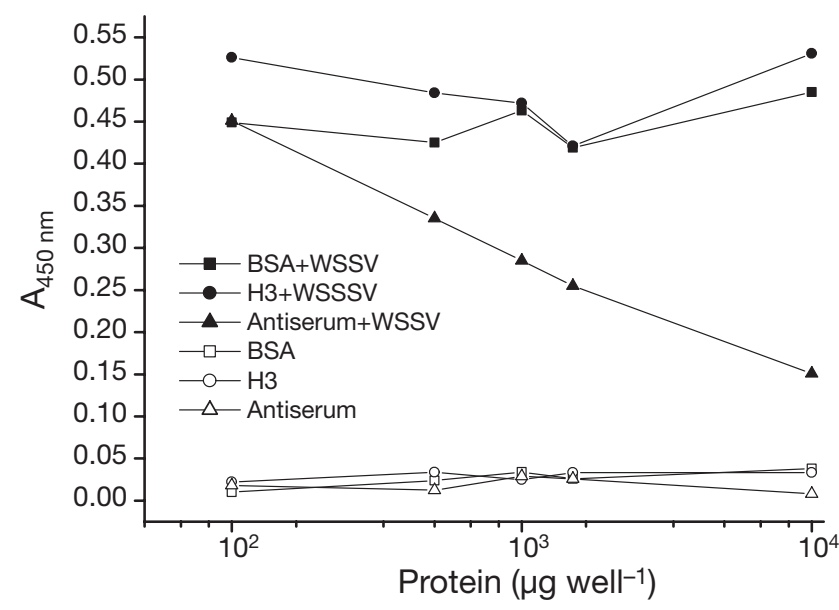

Fig. 5. In vitro assay for neutralization of WSSV by a porcine polyclonal antiserum that was (+) or was not (-) pre-incubated with WSSV $\left(20 \mu \mathrm{g}\right.$ viral protein well $\left.^{-1}\right)$

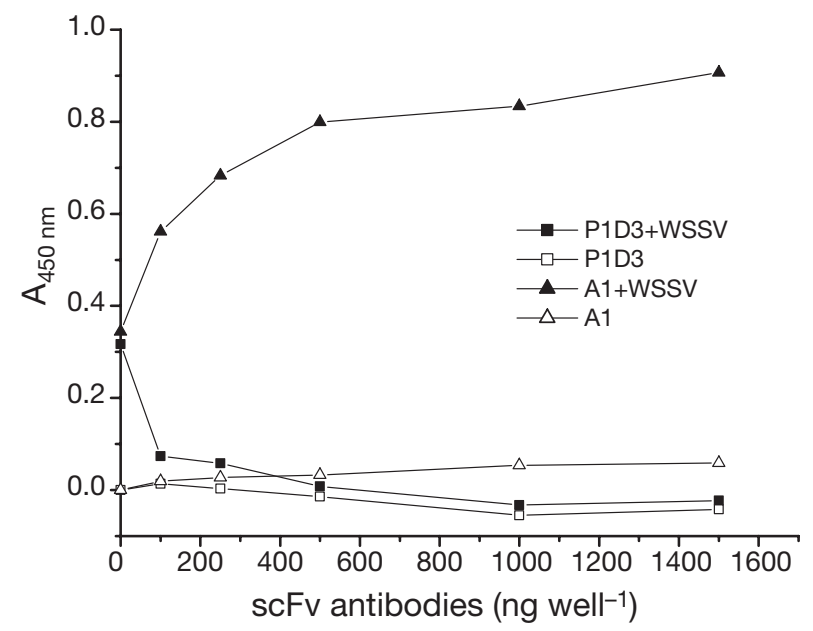

Fig. 6. In vitro screen for neutralization of WSSV by $\mathrm{ScFv}$ antibodies

After overnight primary cell culture, various amounts of partially purified porcine polyclonal antibody against WSSV were pre-incubated with WSSV (20 $\mu \mathrm{g}$ WSSV protein per well), and mixtures were added to the cell culture wells. Virus bound on cells was detected as described in 'Materials and methods'. When incubated with the primary culture in the absence of added WSSV, increasing amounts of BSA, $\mathrm{scFv} \mathrm{H} 3$ or porcine antiserum produced only a constant, low ELISA signal (Fig. 5). Compared with equal amounts of BSA or H3 (an unrelated ScFv protein), the porcine polyclonal antibody against WSSV inhibited virus binding to the cells (Fig. 5). This result demonstrated that the screening method was feasible to assay for specific antibodies that inhibited viral attachment to host cells. In other experiments, we found that the porcine polyclonal antibody against WSSV could neutralize viral infections in shrimp (data not shown).

\section{Screening for neutralizing ScFv antibody against WSSV}

Following the method described above, serial dilutions of active scFv antibodies A1 and P1D3 were preincubated with WSSV and then incubated with primary cultured cells. After washing and fixing, attached virions on the cells were detected by ELISA. Increasing the amount of P1D3 antibody inhibited virus attachment to the host cells, whereas A1 showed no inhibitory activity (Fig. 6). In several independent repetitions of this experiment, P1D3 consistently appeared to inhibit WSSV binding to cells, whereas A1 did not. The increasing ELISA signal with increasing amounts of A1 pre-incubated with WSSV reflects increased amounts of E-tagged A1 antibody specifically associated with WSSV particles that are attached to cells.

\section{DISCUSSION}

Research into the molecular mechanisms of viral diseases of many animals used in aquaculture is restricted by the lack of continuous cell lines with which to conduct experiments. Our results indicate that phage display technology combined with primary cell culture can be used to overcome this obstacle to some extent. Phage display is a powerful tool to produce diverse $\mathrm{scFv}$ antibodies that have similar characteristics to conventional monoclonal antibodies with respect to specificity. Identification of a neutralizing $\mathrm{scFv}$ antibody potentially enables the identification of host cell receptors.

Our results show that primary cell cultures are sufficient for the screening of $\mathrm{scFv}$ antibodies that inhibit virus binding to shrimp cells. P1D3, a neutralizing scFv antibody against WSSV, has been successfully identified by these methods. In the future it may facilitate studies of the virus life-cycle and infection mechanism, and may have potential with respect to protecting shrimp against WSSV.

We noted a high degree of similarity between the primary structures of P1D3 and A1, despite their distinct activities. These distinct activities may due to the highly variable amino acid sequences in the complementarity determining regions (CDRs). Further study is required to determine the structural bases for the observed differences in activities. Although A1 seemed to show much higher binding activity for WSSV than P1D3 (Fig. 2), it could not inhibit binding of WSSV to lymphoid cells (Fig. 6). It is known that binding activity of an antibody is correlated with its binding affinity and the amount of its target antigen. However, the ability of an antibody to inhibit viral attachment to cells depends on whether the antibody can bind to the 
viral proteins that are involved in attachment and membrane fusion (Froyen \& Billiau 1997, Olson et al. 1999). These $2 \mathrm{scFv}$ antibodies should bind to different WSSV proteins. Since scFv P1D3 could inhibit viral attachment to host cells, we deduced that the antigen for $\mathrm{ScF}$ P1D3 could be a protein involved in the process of viral entry.

In recent years, some exciting progress has been made using 'vaccination' despite the fact that invertebrates lack a true adaptive immune response system and seem to rely only on innate immune responses (Kimbrell \& Beutler 2001). The lipopolysaccharide and $\beta$-1,3-glucan binding protein gene is up-regulated in WSSV infected shrimp (Roux et al. 2002). Furthermore, it was found that dietary $\beta-1,3$-glucan can to some extent improve immunity and survival of Penaeus monodon challenged with WSSV (Chang et al. 2003). Oral administration of VP19 and VP28 structural proteins from WSSV virions also provides some protection against WSSV infection (Witteveld et al. 2003, 2004). Identification of a neutralizing $\mathrm{ScFv}$ antibody against WSSV may lead to a new way of preventing or curing white spot disease. $\mathrm{ScFv}$ antibody can be produced quickly and cheaply from phage display antibody libraries, without the need for prior antigen purification or specialized equipment. In addition, it can be produced in large amounts in bacterial hosts, so that the need to immunize animals is eliminated. With such unlimited supplies, the reagents could be added to aquaculture feed in order to test their ability to prevent white spot disease.

Acknowledgements. This work was supported by the Chinese Academy of Sciences Program of Innovation Direction (KSCX2-SW-302-7), NSFC projects $(30170727,30471339)$ and China 863 Program (2001AA620602). We thank T. Xu for assistance with figure modification.

\section{LITERATURE CITED}

Anil TM, Shankar KM, Mohan CV (2002) Monoclonal antibodies developed for sensitive detection and comparison of white spot syndrome virus isolates in India. Dis Aquat Org 51:67-75

Chang CF, Su MS, Chen HY, Liao IC (2003) Dietary beta-1, 3glucan effectively improves immunity and survival of Penaeus monodon challenged with white spot syndrome virus. Fish Shellfish Immunol 15:297-310

Chou HY, Huang CY, Wang CH, Chiang HC, Lo CF (1995) Pathogenicity of a baculovirus infection causing white spot syndrome in cultured penaeid shrimp in Taiwan. Dis Aquat Org 23:165-173

Dai HP, Gao H, Zhao XY, Dai LF, Zhang XH, Xiao N, Zhao RH, Hemmingsen SM (2003) Construction and characterization of a novel recombinant single-chain variable fragment antibody against white spot syndrome virus from shrimp. J Immunol Methods 279:267-275

Flegel TW (1997) Major viral diseases of the black tiger prawn
(Penaeus monodon) in Thailand. World J Microbiol Biotechnol 13:433-442

Froyen G, Billiau A (1997) Potential therapeutic use of antibodies directed towards HuIFN-gamma. Biotherapy 10: 49-57

Huang J, Song XL, Xu J, Yang CH (1995) Baculoviral bypodermal and hematopoietic necrosis-study on the pathogen and pathology of the shrimp explosive epidemic disease of shrimp. Mar Fish Res 16:1-10

Huang CH, Zhang LR, Zhang JH, Xiao LC, Wu QJ, Chen DH, Li JKK (2001) Purification and characterization of white spot syndrome virus (WSSV) produced in an alternate host: crayfish, Cambarus clarkii. Virus Res 76:115-125

Huang R, Xie Y, Zhang J, Shi Z (2005) A novel envelope protein involved in white spot syndrome virus infection. J Gen Virol 86:1357-1361

Itami T, Maeda M, Kondo M, Takahashi T (1999) Primary culture of lymphoid organ cells and haemocytes of kuruma shrimp, Penaeus japonicus. Methods Cell Sci 21:237-244

Kasornchandra J, Khongpradit R, Ekpanithanpong U, Boonyaratpalin S (1999) Progress in the development of shrimp cell cultures in Thailand. Methods Cell Sci 21:231-235

Kimbrell DA, Beutler B (2001) The evolution and genetics of innate immunity. Nat Rev Genet 2:256-267

Li HX, Meng XL, Xu JP, Lu W, Wang J (2005) Protection of crayfish, Cambarus clarkii, from white spot syndrome virus by polyclonal antibodies against a viral envelope fusion protein. J Fish Dis 28:285-291

Liang Y, Huang J, Yu Y, Xu HS (2002) Study and application on cellular receptors of animal virus. Mar Fish Res 23: 64-70

Lightner DV (1996) A handbook of shrimp pathology and diagnostic procedures for diseases of cultured penaeid shrimp. World Aquaculture Society, Baton Rouge, LA

Liu W, Wang YT, Tian DS, Yin ZC, Kwang J (2002) Detection of white spot syndrome virus (WSSV) of shrimp by means of monoclonal antibodies (MAbs) specific to an envelope protein (28 kDa). Dis Aquat Org 49:11-18

Lo CF, Ho CH, Peng SE, Chen CH and 7 others (1996) White spot syndrome baculovirus (WSBV) detected in cultured and captured shrimp, crabs and other arthropods. Dis Aquat Org 27:215-225

Maeda M, Itami T, Mizuki E, Tanaka R and 5 others (2000) Red swamp crawfish (Procambarus clarkii): an alternative experimental host in the study of white spot syndrome virus. Acta Virol 44:371-374

Mayo MA (2002) A summary of taxonomic changes recently approved by ICTV. Arch Virol 147:1655-1663

Olson WC, Rabut GE, Nagashima KA, Tran DN and 9 others (1999) Differential inhibition of human immunodeficiency virus type 1 fusion, gp120 binding, and CC-chemokine activity by monoclonal antibodies to CCR5. J Virol 73: 4145-4155

Roux MM, Pain A, Klimpel KR, Dhar AK (2002) The lipopolysaccharide and $\beta-1,3$-glucan binding protein gene is upregulated in white spot syndrome virus-infected shrimp. J Virol 76:7140-7149

Poulos BT, Pantoja CR, Bradley-Dunlop D, Aguilar J, Lightner DV (2001) Development and application of monoclonal antibodies for the detection of white spot syndrome virus of penaeid shrimp. Dis Aquat Org 47:13-23

Takahashi Y, Itami T, Kondo M, Maeda M, Fujii R, Tomonaga S, Supamattaya K, Boonyaratpalin S (1994) Electron microscopic evidence of bacilliform virus infection in Kuruma shrimp (Penaeus japonicus). Fish Pathol 29:121-125

Tapay LM, Lu Y, Gose RB, Nadala ECB, Brock JA, Loh PC (1997) Development of an in vitro quantal assay in primary 
cell cultures for a non-occluded baculo-like virus of penaeid shrimp. J Virol Methods 164:37-41

Tsai JM, Wang HC, Leu JH, Hsiao HH, Wang AH, Kou GH, Lo CF (2004) Genomic and proteomic analysis of thirty-nine structural proteins of shrimp white spot syndrome virus. J Virol 78:11360-11370

van Hulten MC, Vlak JM (2001) Identification and phylogeny of a protein kinase gene of white spot syndrome virus. Virus Genes 22:201-7

van Hulten MC, Tsai MF, Schipper CA, Lo CF, Kou GH, Vlak JM (2000a) Analysis of a genomic segment of white spot syndrome virus of shrimp containing ribonucleotide reductase genes and repeat regions. J Gen Virol 81: 307-316

van Hulten MC, Westenberg M, Goodall SD, Vlak JM (2000b) Identification of two major virion protein genes of white spot syndrome virus of shrimp. Virology 266:227-236

van Hulten MC, Witteveldt J, Peters S, Kloosterboer N and 5 others (2001a) The white spot syndrome virus DNA genome sequence. Virology 286:7-22

van Hulten MC, Witteveldt J, Snippe M, Vlak JM (2001b) White spot syndrome virus envelope protein VP28 is involved in the systemic infection of shrimp. Virology 285: $228-233$

Wang CH, Lo CF, Leu JH, Chou CM and 6 others (1995) Purification and genomic analysis of baculovirus associated with white spot syndrome (WSBV) of Penaeus monodon. Dis Aquat Org 23:239-242

Wang YC, Lo CF, Chang PS, Kou GH (1998) Experimental infection of white spot baculovirus in some cultured and wild decapods in Taiwan. Aquaculture 164:221-231

Wang CH, Yang HN, Tang CY, Lu CH, Kou GH, Lo CF (2000)

Editorial responsibility: Timothy Flegel,

Bangkok, Thailand
Ultrastructure of white spot syndrome virus development in primary lymphoid organ cell cultures. Dis Aquat Org 41:91-104

Witteveldt J, Vlak JM, van Hulten MC (2003) Protection of Penaeus monodon against white spot syndrome virus using a WSSV subunit vaccine. Fish Shellfish Immunol 16: 571-579

Witteveldt J, Cifuentes CC, Vlak JM, van Hulten MC (2004) Protection of Penaeus monodon against white spot syndrome virus by oral vaccination. J Virol 78:2057-2061

Wongteerasupaya C, Vickers JE, Sriurairatana S, Nash GL and 6 others (1995) A non-occluded, systemic baculovirus that occurs in cells of ectodermal and mesodermal origin and causes high mortality in black tiger prawn Penaeus monodon. Dis Aquat Org 21:69-77

Wu W, Wang L, Zhang X (2005) Identification of white spot syndrome virus (WSSV) envelope proteins involved in shrimp infection. Virology 332:578-583

Xie XX, Li HY, Xu LM, Yang F (2005) A simple and efficient method for purification of intact white spot syndrome virus (WSSV) viral particles. Virus Res 108:63-67

Yang F, He J, Lin XH, Li Q, Pan D, Zhang XB, X Xu (2001) Complete genome sequence of the shrimp white spot bacilliform virus. J Virol 75:11811-11820

Yi G, Wang Z, Qi Y, Yao L, Qian J, Hu L (2004) Vp28 of shrimp white spot syndrome virus is involved in the attachment and penetration into shrimp cells. J Biochem Mol Biol 37: 726-734

Zhang X, Dai L, Dai H (2006) Studies on expression and biochemical characteristics of single chain fragment variable A1 against white spot syndrome virus of shrimp. Acta Hydrobiol Sin 30:141-145

Submitted: March 24, 2006; Accepted: June 30, 2006

Proofs received from author(s): September 23, 2006 